\title{
PEMBERDAYAAN EKONOMI MASYARAKAT MUSLIM MELALUI KEGIATAN JAM'IYAH ARISAN DI DESA JATIBOGOR KECAMATAN SURADADI KABUPATEN TEGAL
}

\author{
Akhris Fuadatis Sholikha \\ Fakultas Ekonomi dan Bisnis Islam Institut Agama Islam Negeri \\ Purwokerto \\ akhrisfuadatis@iainpurwokerto.ac.id
}

\section{A. Abstarct}

This study aims to examine the factors that influence the level of economic empowerment of Muslim communities through the activities of jam'iyah arisan. Where are the factors that influence the level of community empowerment, namely physical capital, human capital, social capital, empowerment actor groups (KPP) and empowerment. Samples were taken from female jam'iyah members in the village of Jatibogor. This research is a quantitative study using PLS (Partial Least Square) data analysis. The results showed that the empowerment actor group variables, physical capital, human capital, social capital, and empowerment had no effect on empowerment. KPP variables, physical capital, and human capital had no effect on social capital. KPP, physical capital, human capital, and social capital had no effect on empowerment.

Keywords: economic empowerment of Muslim communities, activities of jam'iyah arisan

\section{A. Abstrak}

Penelitian ini bertujuan untuk mengkaji faktor-faktor yang berpengaruh terhadap tingkat keberdayaan ekonomi masyarakat muslim melalui kegiatan jam'iyah arisan. Dimana faktor-faktor yang berpengaruh terhadap tingkat keberdayaan masyarkat yaitu modal fisik, modal manusia, modal sosial, kelompok pelaku pemberdayaan (KPP), dan pemberdayaan. Sampel diambil dari anggota jam'iyah wanita yang ada di desa jatibogor. Penelitian ini merupakan penelitian kuantitatif dengan menggunakan analisis data PLS (Partial Least Square). Hasil penelitian menunjukkan

\section{el-JIZYA}


bahwa variabel Kelompok Pelaku Pemberdayaan (KPP), modal fisik, modal manusia, modal sosial, dan pemberdayaan tidak berpengaruh terhadap keberdayaan. Variabel KPP, modal fisik, dan modal manusia tidak berpengaruh terhadap modal sosial. KPP, modal fisik, modal manusia, dan modal sosial tidak berpengaruh terhadap pemberdayaan.

Kata kunci: pemberdayaan ekonomi masyarakat muslim, kegiatan jam,iyah arisan

\section{A. PENDAHULUAN}

Kehidupan sosial yang terdiri dari individu, keluarga dan masyarakat tidak terlepas dari pranata dan norma-norma yang terkandung di dalamnya. Aturan-aturan dalam bentuk pranata dan norma senantiasa mengarahkan individu-individu maupun masyarakat membentuk suatu komitmen tertentu yang memunculkan perilaku kelompok secara bersama dan simultan. Perilaku tersebut berupa kegiatan bersama antar warga masyarakat seperti adanya kerjasama dan gotong royong, sambatan, dan kegiatan berkaitan dengan adat serta tradisi masyarakat lainnya. Hubungan-hubungan sosial informal yang telah terjalin tersebut merupakan modal sosial yang dapat diperankan pada persoalan-persoalan pembangunan ekonomi yang sifatnya lokal termasuk dalam hal pengentasan kemiskinan, karena hal ini akan lebih mudah untuk dicapai dan biayanya kecil jika terdapat modal sosial yang besar ${ }^{1}$. Pembentukan modal sosial yang besar dapat dimulai dengan suatu kegiatan informal salah satunya melalui kegiatan jam'iyah arisan, yang dalam hal ini memiliki pengaruhterhadap pemberdayaan ekonomi masyarakat muslim yang ada di lingkungan sekitar.

Pemberdayaan ekonomi merupakan sesuatu yang sangat penting karena berkaitan dengan kesejahteraan hidup masyarakat. Pemberdayaan ekonomi bisa dilakukan dengan berbagai macam cara, salah satunya melalui kegiatan arisan ibu-ibu rumahtangga yang dilaksanakan tiap minggu. Berbeda dengan arisan pada umumnya yang hanya kumpulkumpul, kocok arisan lalu selesai. Di tempat kami, arisan ini sering disebut jam'iyah arisan, mengapa bisa disebut jam'iyah, karena di dalam kegiatan tersebut selain arisan, ada juga nilai- nilai religius sebagai tujuan dari

Tonkiss, F. 2000. "Does Social Capital and Economy,” Dalam F. Tonkiss dan A. Pasey (eds.) Trust and Civil Society. New York: St. Martin's dalam penelitian Khumaidi, 2011. Peran Organisasi Kagamaan dalam Pemberdayaan Ekonomi Masyarakat (POKMAS) Perempuan Berbasis Modal Sosial, jurnal Muwazah Vol.3, No. 1, Juli 2011. 
kegiatan tersebut. Masyarakat dalam hal ini berkumpul di rumah ibu-ibu secara bergantian setiap minggunya untuk arisan dan juga untuk membaca al- barzanji, membaca yasin dan tahlil, dan mendengarkan kajian kitab kitab fiqih dari ustadz yang telah ditunjuk. Seperti halnya yang dilakukan oleh mayoritas masyarakat muslimdi Desa Jatibogor Kecamatan Suradadi Kabupaten Tegal. Kegiatan ini full selama satu minggu dilakukan masyarakat desa tersebut, ada yang ikut semuanya dari senin sampai minggu, ada yang hanya satu hari, dua hari, tergantung kemampuan masyarakat individu masing-masing, untuk kaum ibu- ibu biasanya, kegiatan ini dilakukan pada siang sampe sore, dari pukul 14.00- 16.00 WIB, sedangkan untuk kaum bapak- bapak dilakukan setiap malam Minggu dan malam Jumat pada pukul 20.00-22.00.

Kegiatan ini dilakukan oleh masyarakat Jatibogor dengan berbagai macam tujuan, diantaranya adalah investasi tabungan bersama masyarakat secara bergilir, dalam artian masyarakat menabung setiap minggunya dengan harapan uangnya bisa terkumpul banyak, dan bisa diambil sesuai permintaan dan kebutuhan. Beberapa kebutuhan yang biasanya menjadi motif masyarakat mengikuti kegiatan arisan ini adalah, persiapan anak masuk sekolah, membangun ataupun memperbaiki rumah, membeli motor, membeli tanah, persiapan pernikahan, sunatan, dll. Karena hal inilah banyak masyarakat antusias mengikuti jam'iyah arisan sebagai sarana bagi mereka untuk menyisihkan pendapatannya dalam kegiatan tersebut. Masyarakat menilai bahwa ini adalah salah satu alternatif mereka berinvestasi dengan cara ini mereka bisa menyisihkan pendapatanya untuk ditabung. Sedangkan penduduk desa jatibogor mayoritas berprofesi sebagai petani, nelayan, dan pedagang. Mereka yang berprofesi sebagai petani berusaha untuk menabung dengan cara mengikuti jam'iyah arisan ini salah satunya mereka gunakan pada musin tanam, untuk membeli sewa lahan, atau mereka tabung untuk beli tanah, sedangkan yang berprofesi sebagai pedagang mereka menyisihkan pendapatanya setelah pulang dari pasar, berdagang keliling, punya toko untuk menambah modal mereka, biaya untuk sekolah, biaya untuk sewa toko, dll.

Sementara untuk para nelayan. Rata rata yang pergi melaut adalah suami sedangkan istri sebagai ibu rumah tangga, mereka mendapatkan penghasilan dari perusahaan dimana suami mereka bekerja, setiap bulan perusahaan akan mengirim gaji suami mereka ke dalam rekening istri, dari sinilah para kaum istri yang berperan. Mereka berusaha menyisihkan uang belanja mereka untuk mengikuti jam'iyah arisan, berharap nantinya bisa

\section{el-JIZYA}


dipakai untuk keperluan membuat rumah, beli tanah, emas, kendaraan, dll. Karena mereka tahu jika suami mereka sudah tidak melaut lagi, mereka harus punya sesuatu misalnya tanah, rumah, toko, yang nantinya mereka bisa pakai untuk usaha jika sudah di rumah. Inilah salah satu bentuk investasi yaitu menyisihkan pendapatan untuk masa depan.

Selain tujuan di atas, kegiatan masyarakat desa jatibogor tersebut juga bertujuan menuntut ilmu dengan cara mendengarkan ustadz membaca kitab- kitab karya para ulama, membaca yasin dan tahlil, bersholawat dengan cara membaca al-barzanji bersama-sama dan juga sebagai sarana untuk silaturahim warga.

Penelitian ini akan mengkaji faktor-faktor yang berpengaruh terhadap tingkat keberdayaan ekonomi masyarakat muslim melalui kegiatan jam'iyah arisan. Dimana dalam peneltian akan dipaparkan model pemberdayaan yang ada, dimana peneliti akan melihat pemberdayaan ekonomi masyarkat dilihat dari beberapa faktor yaitu modal fisik, modal manusia, modal sosial, kemampuan pelaku pemberdayaan.

\section{B. KAJIAN TEORI \\ 1. Pemberdayaan Ekonomi}

Pemberdayaan adalah proses di mana klien mendapatkan sumber daya pribadi, organisasi, dan komunitas yang memungkinkan mereka untuk mendapatkan kendali lebih besar atas lingkungan mereka dan untuk mencapai aspirasi mereka ${ }^{2}$, sedangkan definisi lain menyebutkan bahwa pemberdayaan adalah kegiatan refleksif, sebuah proses yang dapat diprakarsai dan dipertahankan hanya oleh agen atau subjek yang mencari kekuasaan atau penentuan nasib sendiri. Orang lain hanya dapat membantu dan ikut dalam proses pemberdayaan ini. Mereka melakukannya dengan menyediakan iklim, hubungan, sumber daya, dan sarana prosedural melalui mana orang dapat meningkatkan kehidupan mereka sendiri ${ }^{3}$.

Pemberdayaan adalah proses yang melibatkan penggunaan kreatif dari sumber daya pribadi seseorang untuk mendapatkan dan menggunakan kekuatan untuk mengendalikan keadaan kehidupan seseorang, mencapai tujuan pribadi, dan meningkatkan hubungan dan

\footnotetext{
${ }^{2}$ Hasenfeld,Y. (1987). Power in social work practice. Social Service Review, 61, 479

${ }^{3}$ Simon, B.L. (1990). Rethinking empowerment. Journal of Progressive Human Services, 1, 32
} 
kebaikan komunal ${ }^{4}$. Tujuan pemberdayaan adalah untuk meningkatkan kekuatan pribadi, interpersonal, atau politik klien sehingga mereka dapat mengambil tindakan untuk memperbaiki situasi mereka 5 .

Sehingga pemberdayaan adalah penguatan pemilikan faktorfaktor produksi, penguatan penguasaan distribusi dan pemasaran, penguatan masyarakat untuk mendapatkan gaji/upah yang memadai, dan penguatan masyarakat untuk memperoleh informasi, pengetahuan dan ketrampilan, yang harus dilakukan secara multi aspek, baik dari aspek masyarakatnya sendiri, maupun aspek kebijakannya. Salah satu masalah yang dihadapi oleh masyarakat lemah adalah dalam hal akses untuk memperoleh modal. Dalam pasar uang, masyarakat perdesaan baik yang petani,buruh, pengusaha mikro, pengusaha kecil, dan pengusaha menengah, terus didorong untuk meningkatkan tabungan. Tetapi ketika mereka membutuhkan modal, mereka diperlakukan diskriminatif oleh lembaga keuangan. Sehingga yang terjadi adalah aliran modal dari masyarakat lemah ke masyarakat yang kuat. Lembaga keuangan atas posisinya sebagai perantara, maka didalamnya berbagi resiko dengan borrowers, memberikan informasi kepada borrowers, dan menyediakan likuiditas. Kenyataan yang terjadi, kepada masyarakat lemah dan pengusaha kecil, perlakukan atas ketiga hal tersebut juga diskriminatif. Dan atas perlakuan yang tidak adil itu, masyarakat tidak memiliki kekuatan tawar menawar dengan pihak lembaga keuangan6. Hal inilah yang membuat masyarakat khususnya di lingkungan pedesaan mencari alternatif lain untuk menyisihkan pendapatanya melalui kegiatan jam'iyah arisan. Masyarakat memiliki beberapa tujuan yaitu mengaji, menabung, dan silaturrahmi antar warga. sehingga penulis tertarik untuk melihat dari sisi pemberdayan ekonomi melalui kegiatan warga tersebut.

\section{Model Pemberdayaan Ekonomi Masyarakat}

${ }^{4}$ Browne, C.V. (1995). Empowerment in social work practice with older women. Social Work, 40, 358-364.

${ }^{5}$ Gutierrez, L. M., DeLois, K.A., \& GlenMaye, L. (1995). Understanding empowerment practice: Building on practitioner-based knowledge. Families in Society, 76, 534-542.

${ }^{6}$ Mardi Yatmo Hutomo Pemberdayaan Masyarakat dalam Bidang Ekonomi: Tinjauan Teoritik dan Implementasi Naskah No. 20, Juni-Juli 2000. 
Model pemberdayaan ekonomi masyarakat dapat dilakukan melalui beberapa model, yaitu sebagai berikut:

a. Modal fisik (physical capital), yang terdiri dari tiga indikator yaitu:

1) Sarana dan prasarana kegiatan

2) Pendanaan

3) Sarana dan prasarana komunikasi

b. Modal Manusia (human capital), yang terdiri dari satu indikator yaitu:

1) Kemampuan membangun interaksi hubungan/interaksi sesama

c. Modal Sosial (social capital), yang terdiri dari dua indikator yaitu

1) Kepedulian terhadap sesama

2) Keterlibatan dalam aktivitas organisasi sosial

d. Kemampuan Pelaku Pemberdayaan, yang terdiri dari dua indikator yaitu:

1) Aspek kognitif

2) Aspek afektif

e. Pemberdayaan, yang terdiri dari dua indikator yaitu:

1) Kualitas dan kuantitas anggota yang terlibat dalam jam'iyah arisan

2) Perencanaan program, pelaksanakan program, serta keterlibatan dalam evaluasi secara berkelanjutan

f. Keberdayaan Masyarakat, yang terdiri dari dua indikator yaitu:

1) Kemampuan dalam pengambilan keputusan

2) Kemampuan memanfaatkan hasil kegiatan untuk masa depan ${ }^{7}$.

\section{Teori Struktural Fungsional}

Masyarakat sebagai sebuah struktur sosial terdiri atas jaringan hubungan sosial yang kompleks antara anggota-anggotanya. Satu hubungan sosial antara dua orang anggota tertentu pada suatu waktu tertentu, di tempat tertentu, tidak dipandang sebagai satu hubungan yang berdiri sendiri, tetapi merupakan bagian dari satu jaringan hubungan sosial yang lebih luas, yang melibatkan keseluruhan anggota masyarakat tersebut. Hubungan kedua orang di atas harus dilihat

\footnotetext{
${ }^{7}$ Kesi Widjajanti. 2011. Model Pemberdayaan Masyarakat. Jurnal Ekonomi Pembangunan
} Volume 12, Nomor 1, Juni 2011: 15-27 
sebagai bagian dari satu struktur sosial. Inilah prinsip dan objek kajian ilmu sosial. Individu-individu yang menjadi komponen dari sebuah struktur sosial bukanlah dilihat dari sudut biologis, yaitu yang terdiri dari sel-sel dan cairan, tetapi sebagai person yang menduduki posisi, atau status, di dalam struktur sosial tersebut. Orang sebagai organisme biologis, yang terdiri dari sel-sel dan cairan, tidak menjadi perhatian utama ilmu sosial. Yang diperhatikan ilmu sosial adalah orang sebagai status sosial; orang berhubungan dengan orang lain dalam kapasitasnya sebagai sebuah status sosial, misalnya sebagai ayah, ibu, buruh, majikan, penjual, pembeli, dan seterusnya.

\section{Kerangka Pemikiran}



Hipotesis dalam penelitian ini yaitu sebagai berikut:

H1. Variabel modal fisik berpengaruh terhadap modal manusia

$\mathrm{H} 2$. Variabel modal fisik berpengaruh terhadap modal sosial

H3. Variabel modal manusia berpengaruh terhadap modal sosial

H4. Variabel kelompok pelaku pemberdayaan berpengaruh terhadap pemberdayaan

H5. Variabel kelompok pelaku pemberdayaan berpengaruh terhadap keberdayaan

H6. Variabel pemberdayaan berpengaruh terhadap keberdayaan

H7. Variabel modal fisik berpengaruh terhadap keberdayaan melalui variabel modal sosial dan pemberdayaan

H8. Variabel modal manusia berpengaruh terhadap keberdayaan melalui variabel modal sosial dan pemberdayaan

H9. Variabel modal fisik berpengaruh terhadap keberdayaan

H10. Variabel modal manusia berpengaruh terhadap keberdayaan 


\section{METODE PENELITIAN DAN TEHNIK ANALISIS DATA}

\section{Jenis dan lokasi Penelitian}

Penelitian ini merupakan penelitian kuantitatf, dengan menggunakan analisis data PLS (Partial Least Square). Lokasi penelitian yang dilakukan adalah di Desa Jatibogor Kecamatan Suradadi Kabupaten Tegal. Adapun waktu penelitian ini dilaksanakan selama kurang lebih 3 bulan, yang dimulai pada bulan Juni sampai dengan Agustus 2018.

\section{Subjek dan Objek Penelitian}

Dalam penelitian ini yang menjadi subjek penelitian adalah anggota jam'iyah arisan yang ada di Desa Jatibogor Kecamatan Suradadi Kabupaten Tegal. Adapun yang menjadi objek dalam penelitian ini adalah kontribusi kegiatan jam'iyah arisan dalam pemberdayaan ekonomi masyarakat muslim.

\section{Sumber Data}

Sumber data yang penulis gunakan dalam penelitian ini, yaitu:

\section{a. Primer}

Dalam penelitian ini, data primer diperoleh dengan melakukan wawancara terhadap responden, dan data hasil angket kuesioner oleh respoden, data wawancara langsung ke ketua jam'iyah, ulama, dan pemerintah desa setempat.

b. Data sekunder

Data sekunder yaitu data yang diperoleh dari sumber data seperti studi pustaka dan refernsi lainnya yang relevan dengan penelitian. Sedangkan data sekunder dalam penelitian ini bersumber dari jurnal, buku yang terkait dengan masalah yang diteliti.

\section{Metode Pengumpulan Data}

a. Observasi

Observasi adalah suatu cara pengumpulan data dengan pengamatan langsung terhadap suatu obyek dalam suatu periode tertentu dan mengadakan pencatatan secara sistematis tentang halhal tertentu yang diamati (Sutrisno Hadi, 1982). Dalam praktiknya penulis secara langsung mengamati kegiatan jam'iyah arisan di desa jatibogor, apakah memiliki pengaruh terhadap pemberdayaan ekonomi masyarakat muslim, supaya penulis mendapatkan data yang akurat mengenai pemberdayaan ekonomi masyarakat muslim 
melalui kegiatan jam'iyah arisan di desa jatibogor kecamatan suradadi kabupaten tegal.

b. Wawancara

Wawancara ini penulis lakukan terhadap para pengelola jam'iyah arisan di Desa Jatibogor.

c. Dokumentasi

Penulis memperoleh data dokumentasi melalui kegiatan jam'iyah arisan.

d. Definisi operasional varaiabel penelitian

1) Modal fisik (physical capital), yang terdiri dari tiga indikator yaitu:

- Sarana dan prasarana kegiatan

- Pendanaan

- Sarana dan prasarana komunikasi

2) Modal Manusia (human capital), yang terdiri dari satu indikator yaitu:

- Kemampuan membangun interaksi hubungan/interaksi sesame

3) Modal Sosial (social capital), yang terdiri dari dua indikator yaitu

- Kepedulian terhadap sesama

- Keterlibatan dalam aktivitas organisasi sosial

4) Kemampuan Pelaku Pemberdayaan, yang terdiri dari dua indikator yaitu:

- Aspek kognitif

- Aspek afektif

5) Pemberdayaan, yang terdiri dari dua indikator yaitu:

- Kualitas dan kuantitas anggota yang terlibat dalam jam'iyah arisan

- Perencanaan program, pelaksanakan program, serta keterlibatan dalam evaluasi secara berkelanjutan

6) Keberdayaan Masyarakat, yang terdiri dari dua indikator yaitu:

- Kemampuan dalam pengambilan keputusan

- Kemampuan memanfaatkan hasil kegiatan untuk masa depan 


\section{Teknik Analisis Data}

Dalam melakukan analisa data, penulis menggunakan metode PLS (Partial Least Square). PLS terdiri atas hubungan eksternal (outer model atau model pengukuran) dan hubungan internal (inner model atau model struktural). Inner Model ini menitikberatkan pada model struktur variabel laten, dimana antar variabel laten diasumsikan memiliki hubungan yang linier dan memiliki hubungan sebab-akibat, sedangkan outer model yaitu membangun hubungan antara sekumpulan indikator dengan variabel latennya. Outer model mengacu pada model pengukuran. Ada tiga cara membangun antara indikator dengan variabel laten, yaitu hubungan reflektif, hubungan formatif, dan MIMIC (Multi Effect Indicators for Multiple Causes).

Berikutnya adalah menilai weight relation yang digunakan untuk mengestimasi nilai dari variabel laten, selanjutnya menggunakan Evaluasi Model Pengukuran yaitu sebagai berikut:

a. Composite Reliability $(\rho \mathrm{c})$

Nilai Composite Reliability ( $\rho \mathrm{c}$ ) digunakan untuk mengukur konsistensi dari blok indikator. Direkomendasikan nilai Composite Reliability $(\rho c)$ lebih besar dari 0,6.

b. Convergen Validity

Convergen Validity dilihat berdasarkan korelasi antar skor item/indikator dengan skor variabel laten. Ukuran reflektif individual dikatakan tinggi jika berkorelasi lebih dari 0,7 dengan variabel laten yang ingin diukur.

c. Discriminant Validity

Validitas Diskriminan indikator dapat dilihat pada cross-loading antara indikator dengan variabel latennya. Jika korelasi variabel laten dengan indikator lebih besar daripada ukuran variabel laten lainnya, maka hal itu menunjukkan bahwa konstruk laten memprediksi ukuran pada blok mereka lebih baik daripada ukuran blok lainnya.

d. Evaluasi Model Struktural Kualitas model struktural dievaluasi melalui pengujian indeks pengukuran yaitu R2 Pengujian Hipotesis PLS tidak mengasumsikan data berdistribusi normal, sebagai gantinya PLS bergantung pada prosedur bootstrap nonparametrik untuk menguji signifikansi koefisiennya. 


\section{PEMBAHASAN}

\section{Deskripsi Objek Penelitian}

\section{Gambaran Umum Desa Jatibogor}

Desa Jatibogor merupakan desa di sebelah timur Kabupaten Tegal, dengan luas tanah 482,500, dan luas desa 535.000, penduduk desa berprofesi sebagai petani, nelayan, pedagang, pelaut, peternak, buruh, perantau, dsb. Sementara itu batas desa Jatibogor yaitu sebagai berikut:
a. Utara : Sidoharjo
b. Selatan : Karang Mulya
c. Timur : Jatimulya Kecamatan Suradadi
d. Barat : Tanjung Harja Kecamatan Kramat

Semua responden dalam penelitian ini adalah wanita, karena setelah peneliti melakukan wawancara dengan anggota jam'iyah laki laki, hasil wawancara menunjukkan bahwa untuk kaum laki-laki, mereka hanya mengadakan jam'iyah saja, dan iuran kas, tetapi tidak ada arisan dalam kegiatan jam'iyah, sehingga peneliti menentukan responden penelitian hanya untuk kaum wanita.

\section{Data Umur Responden}

\section{Tabel 1}

Data Umur Responden

\begin{tabular}{llll}
\hline No & Umur & Jumlah Responden & $\%$ \\
\hline 1 & $20-29$ tahun & 14 orang & $16 \%$ \\
2 & $30-39$ tahun & 24 orang & $28 \%$ \\
3 & $40-49$ tahun & 18 orang & $21 \%$ \\
4 & $50-59$ tahun & 18 orang & $21 \%$ \\
5 & $60-69$ tahun & 10 orang & $11 \%$ \\
6 & $70-79$ tahun & 3 orang & $3 \%$ \\
\hline \multicolumn{3}{l}{ Jumlah } & 87 orang \\
\hline \multicolumn{4}{c}{ Sumber: Data Excel diolah, 2018 }
\end{tabular}

Berdasarkan data pada tabel diatas menunjukkan bahwa responden terbesar berada pada umur lebih dari 20 tahun yaitu 24 orang, sedangkan responden paling sedikit berada pada umur lebih dari 70 tahun yaitu 3 orang, sementara itu responden dengan umur 
lebih dari 40 tahun dan lebih dari 50 tahun memiliki jumlah yang sama yaitu 18 orang.

\section{Data Pendidikan Responden}

\section{Tabel 2}

\section{Data Pendidikan Responden}

\begin{tabular}{llll}
\hline No & Pendidikan & Jumlah Responden & $\%$ \\
\hline 1 & Tidak Sekolah & 3 orang & $16 \%$ \\
2 & SD & 62 orang & $28 \%$ \\
3 & SMP & 1 orang & $21 \%$ \\
4 & SMA & 19 orang & $21 \%$ \\
5 & S1 & 2 orang & $11 \%$ \\
\hline Jumlah & 87 orang & $100 \%$ \\
\hline \multicolumn{4}{c}{ Sumber: Data Excel diolah, 2018 }
\end{tabular}

Berdasarkan data pada tabel diatas menunjukkan bahwa responden terbesar memiliki pendiidkan terakhir SD yaitu 62 orang, sedangkan responden paling sedikit dengan pendidikan terakhir SMP yaitu 1 orang.

\section{Data Pekerjaan Responden}

Tabel 3

Data Pekerjaan Responden

\begin{tabular}{llll}
\hline No & Pekerjaan & Jumlah Responden & $\%$ \\
\hline 1 & Tani & 3 orang & $16 \%$ \\
2 & Pedagang & 62 orang & $28 \%$ \\
3 & Buruh & 1 orang & $21 \%$ \\
4 & Ibu Rumah Tangga & 19 orang & $21 \%$ \\
5 & Guru & 1 orang & $11 \%$ \\
\hline Jumlah & 87 orang & $100 \%$ \\
\hline
\end{tabular}

Sumber: Data Excel diolah, 2018

Berdasarkan data pada tabel diatas menunjukkan bahwa responden terbesarbekerja sebagai pedagang, paling sedikit bekerja sebagai buruh, dan guru. 


\section{Tehnik Pengolahan Data}

a. Menilai Validitas dan Reliabilitas Konstruk

\section{Tabel 4 \\ Output Adjusted Validitas dan Reliabilitas Konstruk}

Sumber: Data PLS diolah, 2018

\begin{tabular}{lll}
\hline Var. & Cronbachs Alfa & Reliabilitas Konstruk \\
\hline Var. KPP & 0,935 & 0,942 \\
Var. Modal Fisik & 0,865 & 0,899 \\
Var. Keberdayaan & 1 & 1 \\
Var. Modal Manusia & 0,862 & 0,897 \\
Var. Modal Sosial & 0,900 & 0,923 \\
Var. Pemberdayaan & 0,870 & 0,921 \\
\hline
\end{tabular}

Berdasarkan pada data diatas diketahui bahwa uji validitas dengan menggunakan nilai Cronbachs Alfa untuk semua variabel memiliki nilai lebih dari 0,06 sehingga memenuhi kriteria validitas. Dalam hal ini validitas variabel diterima. Sedangkan untuk uji reliabilitas, semua

Variabel memiliki nilai reliablitias konstruk lebih dari 0,7 dan mendekati nilai 1 yang menunjukkan hubungan antar variabel semakin erat.

b. Menilai R Square

\section{Tabel 5}

Output Adjusted R Square

\begin{tabular}{lll}
\hline Var. & R Square & Adj R Square \\
\hline Var. Keberdayaan & 0,571 & 0,550 \\
Var. Modal Manusia & 0,610 & 0,605 \\
Var. Modal Sosial & 0,723 & 0,713 \\
Var. Pemberdayaan & 0,424 & 0,417 \\
\hline & \multicolumn{2}{c}{ Sumber: Hasil olah data PLS, 2018 }
\end{tabular}

Hasil tabel diatas menunjukkan bahwa output data adjusted $\mathrm{R}$ Square untuk variabel keberdayaan sebesar 0,550 sehingga 55 persen variasi variabel keberdayaan dapat dijelaskan oleh variasi variabel modal fisik, modal manusia, modal sosial, kemampuan pelaku pemberdayaan, dan pemberdayaan, sedangkan45 persen dapat dijelaskan oleh variabel-variabel lain yang tidak diteliti. 
Output data adjusted $\mathrm{R}$ Square untuk variabel modal manusia sebesar 0,605 sehingga 60,5 persen variasi variabel modal manusia dapat dijelaskan oleh variasi variabel modal fisik, sedangkan 39,5 persen dapat dijelaskan oleh variabel-variabel lain yang tidak diteliti. Output data adjusted R Square untuk variabel modal sosial sebesar 0,713 sehingga 71,3 persen variasi variabel modal sosial dapat dijelaskan oleh variasi variabel modal fisik, dan modal manusia sedangkan38,7 persen dapat dijelaskan oleh variabelvariabel lain yang tidak diteliti. Sedangkan output data adjusted R Square untuk variabel modal pemberdayaan sebesar 0,417 sehingga 41,7 persen variasi variabel modal sosial dapat dijelaskan oleh variasi variabel modal fisik, dan modal manusia, modal sosial, dan kemampuan pelaku pemberdayaan, sedangkan58,3 persen dapat dijelaskan oleh variabel-variabel lain yang tidak diteliti.

c. Koefisien Jalur

\section{Tabel 6}

Koefisien Jalur

\begin{tabular}{|c|c|c|c|c|c|c|}
\hline & Var KPP & Var. MF & Var. Keberdayaan & Var. MM & Var. MS & Var. Pemberdayan \\
\hline Var. KPP & & & $-0,134$ & & & \\
\hline Var MF & & & $-0,104$ & 0,781 & 0,343 & \\
\hline
\end{tabular}

Var.Keberdayaan

Var. MM

0,263

0,252

Var. MS

Var.Pemberdayan

0,730

Sumber: Hasil olah data PLS, 2018

Keterangan:

Var. KPP= Variabel Kelompok Pelaku Pemberdayaan

Var. $\mathrm{MF}=$ Variabel Modal Fisik

Var. $\mathrm{MM}=$ Variabel Modal Manusia

Var. MS= Variabel Modal Sosial

Hasil tabel diatas menunjukkan bahwa nilai signifikansi dari semua variabel menunjukkan nilai kurang dari 0,05 hal ini membuktikan bahwa variabel modal fisik, modal manusia, pemberdayaan, KPP tidak berpengaruh terhadap keberdayaan. Modal fisik tidak berpengaruh terhadap modal manusia, modal fisik tidak berpengaruh terhadap modal sosial, modal manusia tidak 
berpengaruh terhadap modal sosial, dan modal socsal tidak berpengaruh terhadap pemberdayaan.

d. Efek tidak langsung

\section{Tabel 7}

\section{Efek tidak langsung}

\begin{tabular}{|c|c|c|c|c|c|c|}
\hline & Var KPP & Var. MF & Var. Keberdayaan & Var. MM & Var. MS & Var. Pemberdayan \\
\hline Var. KPP & & & 0,162 & & & 0,222 \\
\hline Var MF & & & 0,462 & & 0,196 & 0,351 \\
\hline
\end{tabular}

Var.Keberdayaan

Var. MM

0,119

0,164

Var. MS

0,475

Var.Pemberdayan

Sumber: Hasil olah data PLS, 2018

Hasil tabel diatas menunjukkan bahwa nilai signifikansi dari semua variabel menunjukkan nilai kurang dari 0,05 hal ini membuktikan bahwa variabel KPP, modal fisik, modal manusia, dan modal sosial tidak berpengaruh terhadap keberdayaan. Modal fisik tidak berpengaruh terhadap modal manusia, modal KPP tidak berpengaruh terhadap pemberdayaan, modal fisik tidak berpengaruh terhadap pemberdayaan, dan modal manusia tidak berpengaruh terhadap pemberdayaan.

e. Pengaruh Total

\section{Tabel 8}

\section{Pengaruh Total}

\begin{tabular}{|c|c|c|c|c|c|c|}
\hline & Var KPP & Var. MF & Var. Keberdayaan & Var. MM & Var. MS & Var. Pemberdayan \\
\hline Var. KPP & & & 0,028 & & 0,341 & 0,222 \\
\hline Var MF & & & 0,358 & 0,781 & 0,540 & 0,358 \\
\hline
\end{tabular}

Var.Keberdayaan

\begin{tabular}{|c|c|}
\hline Var. MM & 0,383 \\
\hline & 0,475 \\
\hline
\end{tabular}

Var. Pemberdayan $\quad 0,730$

Sumber: Hasil olah data PLS, 2018

Hasil tabel diatas menunjukkan bahwa nilai signifikansi dari semua variabel menunjukkan nilai kurang dari 0,05 hal ini 
membuktikan bahwa variabel KPP, modal fisik, modal manusia, modal sosial, dan pemberdayaan tidak berpengaruh terhadap keberdayaan. Variabel KPP, modal fisik, dan modal manusia tidak berpengaruh terhadap modal sosial. KPP, modal fisik, modal manusia, dan modal sosial tidak berpengaruh terhadap pemberdayaan.

\section{Pembahasan}

Modal fisik tidak berpengaruh terhadap modal manusia. Hal ini membuktikan bahwa fasilitas yang digunakan untuk mendukung kegiatan seperti sarana prasarana kegiatan, pendanaan, dan sarana prasarana komunikasi tidak mempengaruhi modal manusia yaitu asset yang berkaitan dengan kemampuan untuk melakukan suatu aktivitas dalam hal ini kemampuan untuk membangun interaksi.

Modal manusia tidak berpengaruh terhadap modal sosial. Hal ini membuktikan bahwa kemampuan untuk membangun interaksi sesama tidak mempengaruhi modal social yaitu suatu norma yang dapat mempengaruhi dan memperkuat jaringan sosial yaitu kepedulian terhadap sesama, dan keterlibatan dalam aktivitas organisasi sosial.

Modal fisik tidak berpengaruh terhadap modal social. Hal ini membuktikan bahwa fasilitas yang digunakan untuk mendukung kegiatan seperti sarana prasarana kegiatan, pendanaan, dan sarana prasarana komunikasi tidak mempengaruhi kepedulian terhadap sesama dan keterlibatan dalam aktivitas organisasi.

Kelompok pelaku pemberdayaan tidak berpengaruh terhadap pemberdayaan. Hal ini membuktikan bahwa kemampuan yang dimiliki pengurus anggota jam'iyah yaitu aspek kognitif dan afektif tidak mempengaruhi pemberdayaan yaitu suatu proses untuk bekerja bersama untuk mencapai tujuan kelompok bersama yaitu kualitas dan kuantitas anggota yng terlibat serta perencanaan program, pelaksanaan, dan keterlibatan dalam evaluasi secara berkelanjutan.

Modal sosial tidak berpengaruh terhadap pemberdayaan. Hal ini membuktikan bahwa kepedulian terhadap sesama, dan keterlibatan 
dalam aktivitas organisasi sosial tidak mempengaruhi kualitas dan kuantitas anggota yang terlibat serta perencanaan program, pelaksanaan, dan keterlibatan dalam evaluasi secara berkelanjutan.

Pemberdayaan tidak berpengaruh terhadap keberdayaan. Hal ini membuktikan bahwa kualitas dan kuantitas anggota yng terlibat serta perencanaan program, pelaksanaan, dan keterlibatan dalam evaluasi secara berkelanjutan tidak mempengaruhi masyarakat untuk bisa berdaya yang ditandai oleh kemampuan untuk pengambilan keputusan, dan kemampuan untuk memanfaatkan hasil di masa depan.

Modal fisik tidak berpengaruh terhadap keberdayaan. Hal inin membuktikan bahwa fasilitas yang digunakan untuk mendukung kegiatan seperti sarana prasarana kegiatan, pendanaan, dan sarana prasarana komunikasi tidak mempengaruhi masyarakat untuk bisa berdaya yang ditandai oleh kemampuan untuk pengambilan keputusan, dan kemampuan untuk memanfaatkan hasil di masa depan.

Modal manusia tidak berpengaruh terhadap keberdayaan. Hal ini membuktikan bahwa kemampuan untuk membangun interaksi sesama tidak mempengaruhi masyarakat untuk bisa berdaya yang ditandai oleh kemampuan untuk pengambilan keputusan, dan kemampuan untuk memanfaatkan hasil di masa depan.

\section{Penutup}

\section{a. Kesimpulan}

Berdasarkan pada tabel koefisien jalur menunjukkan bahwa tidak variabel modal fisik, modal manusia, pemberdayaan, KPP tidak berpengaruh terhadap keberdayaan. Modal fisik tidak berpengaruh terhadap modal manusia, modal fisik tidak berpengaruh terhadap modal sosial, modal manusia tidak berpengaruh terhadap modal sosial, dan modal social tidak berpengaruh terhadap pemberdayaan.

Berdasarkan pada tabel pengaruh tidak langsung menunjukkan bahwa variabel KPP, modal fisik, modal manusia, dan modal sosial tidak berpengaruh terhadap keberdayaan. Modal 
fisik tidak berpengaruh terhadap modal manusia, modal KPP tidak berpengaruh terhadap pemberdayaan, modal fisik tidak berpengaruh terhadap pemberdayaan, dan modal manusia tidak berpengaruh terhadap pemberdayaan.

Berdasarkan pada tabel pengaruh total menunjukkan bahwa variabel KPP, modal fisik, modal manusia, modal social, dan pemberdayaan tidak berpengaruh terhadap keberdayaan. Varaiabel KPP, modal fisik, dan modal manusia tidak berpengaruh terhadap modal social. KPP, modal fisik, modal manusia, dan modal sosial tidak berpengaruh terhadap pemberdayaan.

\section{b. Saran}

Penelitian berikutnya bisa memperluas jangkauan penelitian dengan cara memperbanyak jumlah sampel. Penelitian berikutnya bisa mencari objek penelitian yang bisa mendukung teori model pemberdayaan masyarakat. 


\section{Daftar Pustaka}

Browne, C.V. 1995. Empowerment in social work practice with older women. Social Work

Gutierrez, L. M., DeLois, K.A., \& GlenMaye, L. 1995. Understanding empowerment practice: Building on practitioner-based knowledge. Families in Society

Hutomo, Mardi Yatmo. Pemberdayaan Masyarakat dalam Bidang Ekonomi: Tinjauan Teoritik dan Implementasi

Koentjaraningrat. 1994. Metode-Metode Penelitian Masyarakat. Jakarta: PT. Gramedia Pustaka Utama

Mth Asmuni. 2003. Konsep Pembangunan Ekonomi Islam. Al Mawarid Edisi X

Sutrisno Hadi, Metode Penelitian Reseach, Jilid II (Yogyakarta: Yayasan Penerbit Fakultas Psikologi, UGM, 1982), hlm. 136.

Syamsuri. 2016. Paradigma Pembangunan Ekonomi, Satu Analisis Tinjauan Ulang dari perspektif Ekonomi Islam. Jurnal Ekonomi Islam. Vol. 7 No. 2

Simon, B.L. 1990. Rethinking empowerment. Journal of Progressive Human Services, 1, 32

Trujillo, G.S. PLS Path Modelling with R. Berkeley : Trowchez Editions Tonkiss, F. 2000. "Does Social Capital and Economy," Dalam F. Tonkiss dan A. Pasey (eds.) Trust and Civil Society. New York:St. Martin's dalam penelitian Khumaidi, 2011. Peran Organisasi Kagamaan dalam Pemberdayaan Ekonomi Masyarakat (POKMAS) Perempuan Berbasis Modal Sosial, jurnal Muwazah Vol.3, No. 1, Juli 2011 Widjajanti, Kesi. 2011. Model Pemberdayaan Masyarakat. Jurnal Ekonomi Pembangunan. Vol. 3. No. 1 